\title{
Microwave-assisted synthesis of biologically relevant steroidal 17-exo-pyrazol-5'-ones from a norpregnene precursor by a side-chain elongation/heterocyclization sequence
}

\author{
Gergő Mótyán ${ }^{1}$, László Mérai ${ }^{1}$, Márton Attila Kiss ${ }^{1}$, Zsuzsanna Schelz² ${ }^{2}$ Izabella Sinka ${ }^{2}$, \\ István Zupkó ${ }^{2}$ and Éva Frank ${ }^{* 1}$
}

\section{Full Research Paper}

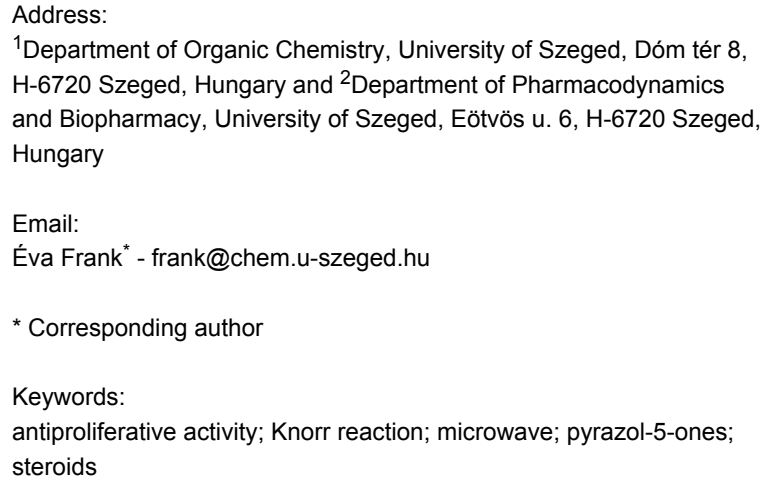

${ }^{1}$ Department of Organic Chemistry, University of Szeged, Dóm tér 8, H-6720 Szeged, Hungary and ${ }^{2}$ Department of Pharmacodynamics and Biopharmacy, University of Szeged, Eötvös u. 6, H-6720 Szeged, Hungary

\author{
Beilstein J. Org. Chem. 2018, 14, 2589-2596. \\ doi:10.3762/bjoc. 14.236 \\ Received: 13 July 2018 \\ Accepted: 25 September 2018 \\ Published: 08 October 2018 \\ Associate Editor: I. R. Baxendale \\ (c) 2018 Mótyán et al.; licensee Beilstein-Institut. \\ License and terms: see end of document.
}

\begin{abstract}
Multistep syntheses of novel $17 \beta$-pyrazol-5'-ones in the $\Delta^{5}$-androstane series were efficiently carried out from pregnenolone acetate. A steroidal 17-carboxylic acid was first synthesized as a norpregnene precursor by the bromoform reaction and subsequent acetylation. Its CDI-activated acylimidazole derivative was then converted to a $\beta$-ketoester containing a two carbon atom-elongated side chain than that of the starting material. A Knorr cyclization of the bifunctional 1,3-dicarbonyl compound with hydrazine and its monosubstituted derivatives in $\mathrm{AcOH}$ under microwave heating conditions led to the regioselective formation of 17-exo-heterocycles in good to excellent yields. The suppression of an acid-catalyzed thermal decarboxylation of the $\beta$-ketoester and thus a significant improvement in the yield of the desired heterocyclic products could be achieved by the preliminary liberation of the arylhydrazines from their hydrochloride salts in $\mathrm{EtOH}$ in the presence of $\mathrm{NaOAc}$. The reaction rates were found to depend on the electronic character of the substituent present in the phenylhydrazine applied. The antiproliferative activities of the structurally related steroidal pyrazol-5'-ones and their deacetylated analogs were screened on three human adherent breast cancer cell lines (MCF7, T47D and MDA-MB-231): the microculture tetrazolium assay revealed that some of the presented derivatives exerted cell growth inhibitory effects on some of these cell lines comparable to those of the reference compound, cisplatin.
\end{abstract}

\section{Introduction}

17-exo-Heterocyclic androstanes with five or six-membered heterocyclic rings connected directly to $\mathrm{C}-17$ of the sterane core represent a remarkable subclass of semisynthetic sex hormone analogs in consequence of their dual pharmacological importance. A number of these derivatives display an inhibitory effect on $17 \alpha$-hydroxylase- $\mathrm{C}_{17,20}$-lyase $\left(\mathrm{P} 40_{17 \alpha}\right)$ enzyme, which, 
acting as an important regulator, plays an essential role in the endogenous production of androgen hormones, and therefore, in the development of prostate cancer [1]. According to extensive structure-activity relationship and docking studies, a potent steroidal inhibitor should possess certain structural characteristics for efficient $\mathrm{P} 450_{17 \alpha}$ inhibition [1-3], such as (i) a five or six-membered non-bulky heterocycle containing $\mathrm{O}, \mathrm{N}$ or $\mathrm{S}$ atoms attached to position $\mathrm{C}-17$ of the sterane skeleton with the lone electron pairs capable of coordinating with the heme iron at the active site; (ii) a $\mathrm{N}$ atom at either position $3^{\prime}$ or $4^{\prime}$ relative to the atom through which the heterocyclic ring is connected to the sterane framework; (iii) a hydroxy or keto group at C-3 and (iv) the presence of a $\mathrm{C}_{16}-\mathrm{C}_{17}$ double bond, which facilitates the inhibitory effect but is not an essential requirement. Some 17-heterocycle-substituted androstanes, even those that lack the structural features described above, are also known to display cytotoxic effects on diverse cancer cells by inducing a disturbance in the cell cycle and promoting apoptosis without affecting normal cellular proliferation [4,5]. In these latter cases, detailed structural criteria are still not available owing to little information about the mode of action of these derivatives.

Amongst steroidal 17-exo-heterocycles, those containing a pyrazole heteroaromatic ring are of special relevance with respect to the above-mentioned bioactivities [6-9]. Interestingly, so far only a few examples of compounds in which a pyrazolone moiety is attached to the sterane skeleton have been published, but not to C-17 [10]. Nevertheless, this heterocyclic scaffold is also an important building block in many clinically relevant drugs, agrochemicals, dyes, pigments and chelating agents [11-13], and therefore its introduction to C-17 of androstanes may be of interest from a pharmacological point of view.

The first and probably most frequently used method for the synthesis of pyrazolones is based on the Knorr condensation of $\beta$-ketoesters with substituted or unsubstituted hydrazines. However, these reactions often suffer from certain disadvantages, such as the necessity of high temperature or prolonged reaction time and low yields of the desired products [14]. A rate acceleration and yield improvement could be achieved in some cases by performing the reactions under microwave (MW) conditions [15-17]. Especially with respect to pyrazol-5-ones, keto-enol tautomerism can be challenging and is of special importance in biological systems, chemical reactivity, and molecular recognition [18]. The tautomeric equilibrium in solution is strongly influenced by the substitution pattern of the heterocyclic ring, the polarity and protic nature of the solvent and, although to a lesser extent, by the temperature and concentration [19].
In view of the above-mentioned reasons, the main objective of the present study was to design and carry out the preparation of novel steroidal heterocycles containing pyrazol-5-one moieties attached to $\mathrm{C}-17$ of the sterane core, using both conventional heating and MW irradiation. The reaction conditions were optimized in order to improve the yields of the desired products and the influences of substituents of the hydrazine reagents investigated. The in vitro antiproliferative activities of the synthesized compounds were also determined on three human breast malignant cell lines (MCF7, T47D, and MDA-MB-231) by means of 3-(4,5-dimethylthiazol-2-yl)-2,5-diphenyltetrazolium bromide (MTT) assay [20]. Furthermore, the most promising molecules were additionally tested on mouse fibroblasts (NIH-3T3) in order to obtain preliminary results concerning the cancer selectivity of the selected agents.

\section{Results and Discussion Synthetic studies}

The steroidal $\beta$-ketoester precursor $\mathbf{4}$, suitable for the attempted heterocyclization reaction with hydrazines was synthesized from commercially available pregnenolone acetate (1) via a multistep sequence (Scheme 1). First compound 1 was converted to the $17 \beta$-carboxylic acid $\mathbf{2 b}$ by the bromoform reaction and subsequent acetylation according to well-known literature procedures [21-23]. After the activation of $2 \mathbf{b}$ with 1,1'carbonyldiimidazole (CDI) as coupling reagent in THF, the magnesium enolate of malonic acid half ester, prepared in situ from potassium methyl malonate, $\mathrm{MgCl}_{2}$ and triethylamine in acetonitrile, was added $[24,25]$. The acylation of magnesium methyl malonate by the preformed imidazole 3 led to the desired bifunctional starting material 4 in good yield (79\%).

Analogously, $\beta$-ketoester 4 ' could be obtained from pregnadienolone acetate $\mathbf{1}^{\prime}$ through a $\Delta^{5,16}$-carboxylic acid intermediate $[23,26]$ under identical conditions albeit in disappointing low yield (33\%) which is presumably caused by the decreased propensity of the conjugated carbonyl compound to react with the magnesium enolate. Although the presence of a $\mathrm{C}_{16}-\mathrm{C}_{17}$ double bond as in $4^{\prime}$ is assumed to be beneficial for a $\mathrm{P}^{\prime} 50_{17 \alpha^{-}}$ inhibitory effect, further transformations of this compound were abandoned because of the insufficient yield and its potential tendency to react with monosubstituted hydrazines - not only with its $\beta$-ketoester moiety to give 17-exo-heterocycles, but also with its enone part to provide ring $\mathrm{D}$-condensed pyrazolines [27].

Therefore, the ring-closure reactions of $\mathbf{4}$ with unsubstituted and monosubstituted hydrazines as binucleophilic reagents were investigated next. First, compound $\mathbf{4}$ was reacted with hydrazine hydrate (5a) in refluxing ethanol containing a catalytic amount of $\mathrm{AcOH}$ (Scheme 2). 


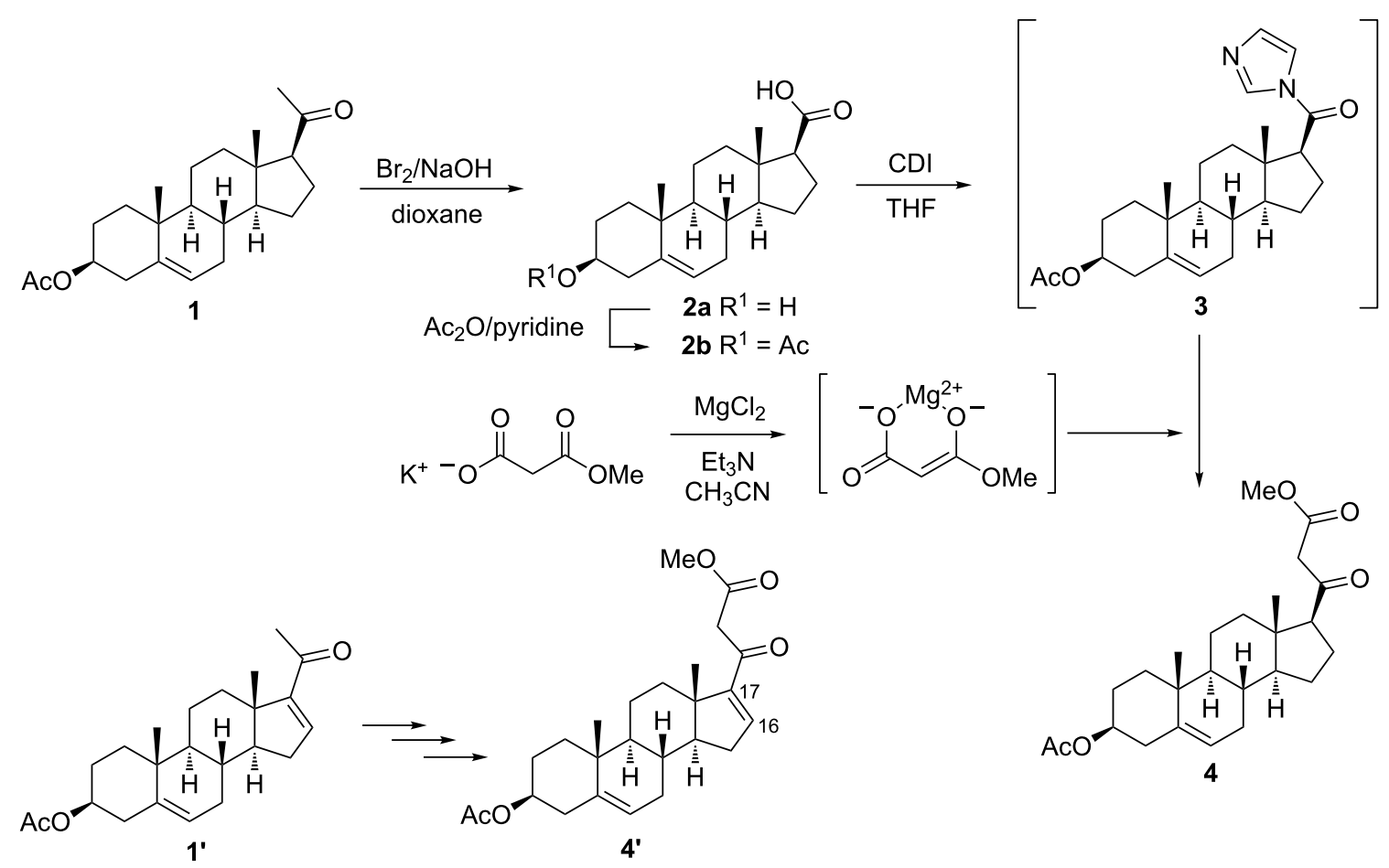

Scheme 1: Multistep synthesis of steroidal $\beta$-ketoesters 4 and 4' from pregnenolone acetate (1) and pregnadienolone acetate (1').

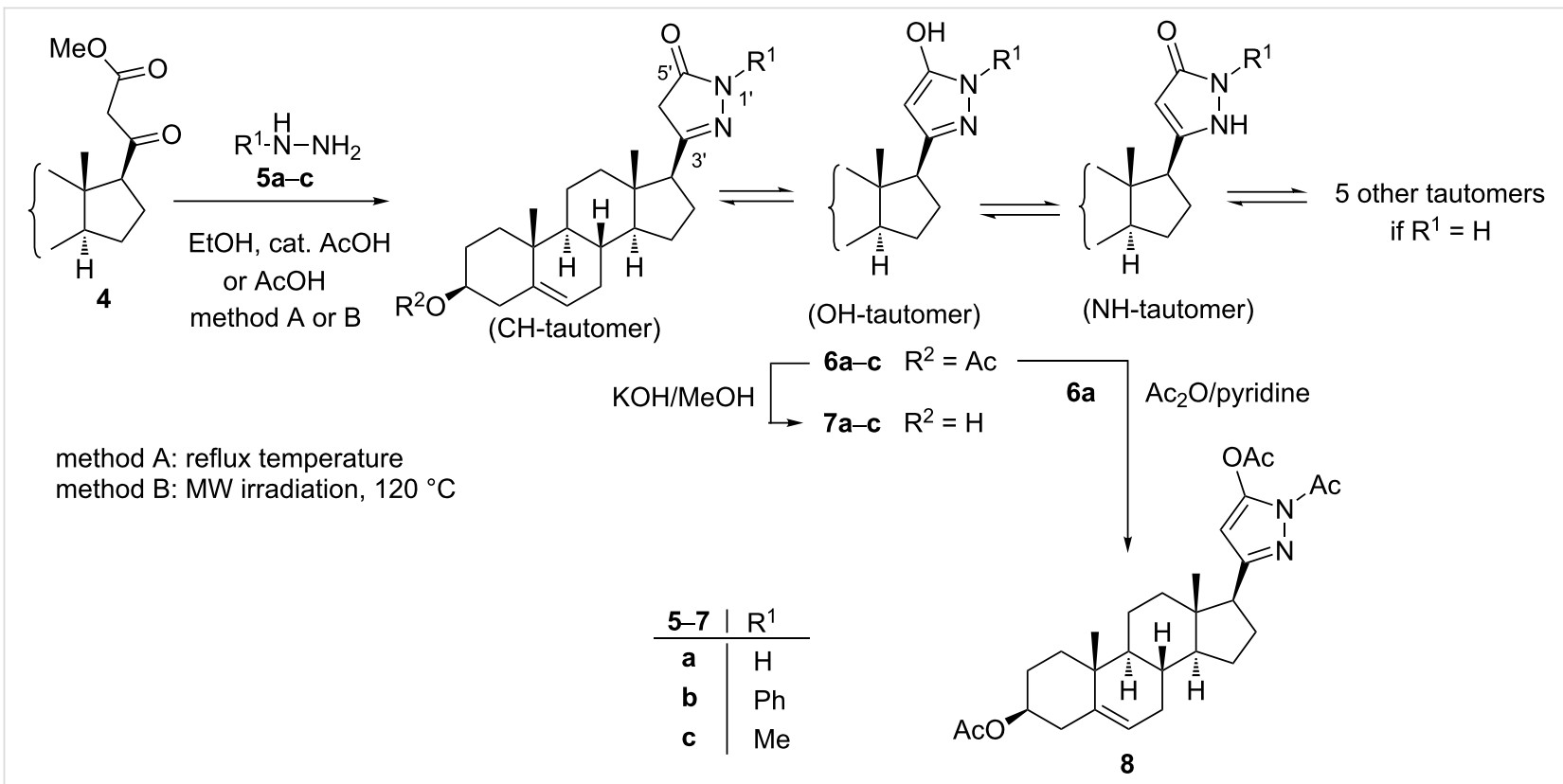

Scheme 2: Cyclization of compound 4 with hydrazine hydrate (5a), phenylhydrazine $(5 b)$ and methylhydrazine $(5 c)$.

TLC monitoring of the reaction indicated full conversion of 4 within $4 \mathrm{~h}$ reaction time to afford a fairly polar product insoluble or only slightly soluble in all commonly used NMR solvents. However, a subsequent derivatization with acetic anhydride in pyridine to afford $\mathbf{8}$, allowed its structure verifica- tion indirectly. This derivatization did not only improve the solubility of the compound, but also eliminated the possibility of prototropic tautomerism through acetylation of both the amino and hydroxy groups present in the heterocyclic ring in 6a. The ${ }^{1} \mathrm{H}$ and ${ }^{13} \mathrm{C}$ NMR spectroscopical analysis confirmed 
the structure of $\mathbf{8}$, which at the same time supported the formation of $\mathbf{6 a}$ in a yield of $84 \%$ during the previous reaction step. While N-unsubstituted pyrazolones such as 6a theoretically may have eight tautomeric forms [28], their $\mathrm{N}\left(1^{\prime}\right)$-substituted derivatives, lacking a functionality on pyrazole $\mathrm{C}-4$, can only exist in three equilibrating tautomers $(\mathrm{OH}, \mathrm{CH}$ and $\mathrm{NH})[18,29]$. Therefore, further heterocyclizations of $\mathbf{4}$ were performed with monosubstituted hydrazine derivatives. The reaction with phenylhydrazine (5b) was completed within $7 \mathrm{~h}$ in refluxing EtOH in the presence of an acid catalyst. A reduction of the reaction time to $3 \mathrm{~h}$ could be achieved by changing the solvent to $\mathrm{AcOH}$ affording the desired product $\mathbf{6} \mathbf{b}$ in high yield $(86 \%$, Scheme 2). On the other hand, the reaction of 4 with methylhydrazine $(5 \mathbf{c})$ required a longer reaction time $(5 \mathrm{~h})$ in refluxing $\mathrm{AcOH}$ to furnish the purified product $(\mathbf{6 c})$ in a diminished yield (61\%). This may be attributed to the weaker nucleophilic character of the external $\mathrm{N}$ compared to the internal one in $\mathbf{5 c}$ [27], in contrast to phenylhydrazine (5b), making the first condensation step more difficult. The regioselectivity of the reactions with monosubstituted hydrazines is controlled by the higher reactivity of the ketone moiety over the ester towards nucleophiles, and the least hindered terminal nitrogen atom of the binucleophiles. Both reactions were repeated in $\mathrm{AcOH}$ under microwave conditions at $120^{\circ} \mathrm{C}$ furnishing products $\mathbf{6 b}$ and $\mathbf{6 c}$ within shorter time (20 $\mathrm{min}$ and $40 \mathrm{~min}$ ), however, without a substantial improvement in the yields.

Since commercially available arylhydrazine hydrochlorides were intended to be applied for further transformations, the reactions of $\mathbf{4}$ with $\mathbf{5 b} \cdot \mathrm{HCl}$ using an equivalent amount of $\mathrm{NaOAc}$ in $\mathrm{AcOH}$, both under conventional heating and MW irradiation, were also carried out. Although similar reaction conditions have been described in the literature for the reactions of methyl acetoacetate with arylhydrazine hydrochlorides to afford the corresponding pyrazol-5-ones in $50-70 \%$ yields within 5-10 h [30], no full conversion of 4 could be achieved. Even after refluxing the mixture for $24 \mathrm{~h}$ the desired product $\mathbf{6 b}$ was obtained only in low yield $(\approx 30 \%)$. At the same time, the use of the $\mathrm{MW}$-assisted method at $120^{\circ} \mathrm{C}$ shortened the conversion time significantly ( $80 \mathrm{~min})$. However, in addition to $\mathbf{6 b}$ $(\approx 50 \%)$, the conventional, and even more the MW-promoted transformations led to a considerable amount (20-25\%) of pregnenolone acetate (1) as a byproduct. The latter is thought to be produced by an acid-catalyzed thermal decarboxylation of $\mathbf{4}$ during the relatively long heating period. Further the unwanted side reaction was attributed to the poor solubility of $\mathbf{5 b} \cdot \mathrm{HCl}$ in $\mathrm{AcOH}$ resulting in a heterogeneous reaction mixture even at high temperature and therefore a slow liberation of $\mathbf{5 b}$ from its salt upon the addition of NaOAc. In order to circumvent this issue, the reaction was repeated with in situ-liberated phenylhydrazine (5b) by dissolving $\mathbf{5 b} \cdot \mathrm{HCl}$ and $\mathrm{NaOAc}$ in a small amount of EtOH under mild heating for $10 \mathrm{~min}$. To this solution, containing $\mathrm{NaCl}$ as the only solid substance, the steroidal dicarbonyl compound $\mathbf{4}$ dissolved in $\mathrm{AcOH}$ was added. The so obtained mixture was then irradiated in a MW reactor at $120^{\circ} \mathrm{C}$ for $20 \mathrm{~min}$. Under these conditions, the corresponding product 6b was obtained in $85 \%$ yield after chromatographic purification without notable formation of $\mathbf{1}$.

After optimizing the conditions for the MW-assisted synthesis of $\mathbf{6 b}$ from $\mathbf{4}$ with $\mathbf{5 b} \cdot \mathrm{HCl}$, analogous heterocyclization reactions were carried out with different substituted phenylhydrazine hydrochlorides $\mathbf{5 d}-\mathbf{j}$. All reactions furnished the corresponding 17-exo-heterocycles $\mathbf{6} \mathbf{d}-\mathbf{j}$ in good to excellent yields (83-92\%, Table 1).

The electronic features of the substituents on the aromatic ring of 5 had a notable influence on the reaction rates. The ringclosure of $\mathbf{4}$ with $\mathbf{5 d}-\mathbf{g}$ containing electron-donating groups (Table 1, entries 1-4) took place within shorter reaction times (5-10 $\mathrm{min}$ ) compared to phenylhydrazine (5b). On the other hand the presence of electron-withdrawing halogens on the aromatic ring of 5 (Table 1, entries 5-7) lengthened the reaction time to $30 \mathrm{~min}$. This observation can be explained by the enhanced or diminished nucleophilic character of the nitrogen atoms caused by the different groups on the aromatic ring in $\mathbf{5}$, favoring or hampering their nucleophilic attack during the intermolecular heterocyclization. In order to enlarge the compound library available for pharmacological studies, the $3 \beta-\mathrm{OH}$ analogs $\mathbf{7 a}-\mathbf{j}$ of the primary products $\mathbf{6 a}-\mathbf{j}$ were also synthesized through simple alkaline deacetylation (Scheme 2, Table 1).

The structures of all synthesized compounds were characterized by ${ }^{1} \mathrm{H}$ and ${ }^{13} \mathrm{C}$ NMR spectroscopy supplemented by IR and MS measurements. The dependence of the tautomeric equilibrium on the polarity of the applied solvent was observed during the NMR experiments. For example, in the ${ }^{1} \mathrm{H}$ NMR spectrum of compound $7 \mathbf{f}$ recorded immediately after dissolution in $\mathrm{CDCl}_{3}$, the pyrazolone heterocyclic ring mainly exists as the $\mathrm{CH}$-tautomeric form (Figure 1). The characteristic signals of the 4'-methylene hydrogens appear at 3.36 and $3.46 \mathrm{ppm}$ in the ${ }^{1} \mathrm{H}$ NMR spectrum. However, in the more polar solvent DMSO$d_{6}$, the equilibrium mixture of the $\mathrm{NH}$ - and $\mathrm{OH}$-tautomers of $\mathbf{7 f}$ predominates. As the activation barrier between these latter isomers is low and their interconversion is rapid on the NMR timescale, only average signals can be observed for the 4'-H and $\mathrm{NH} / \mathrm{OH}$ protons [31].

\section{Pharmacological studies}

The pharmacological activities of the synthesized 17-exoheterocycles $\mathbf{6} \mathbf{a}-\mathbf{j}$ and $\mathbf{7 a}-\mathbf{j}$ were studied in vitro. Their antipro- 
Table 1: Synthesis of steroidal $N\left(1^{\prime}\right)$-aryl-substituted pyrazol-5'-ones ${ }^{a}$.

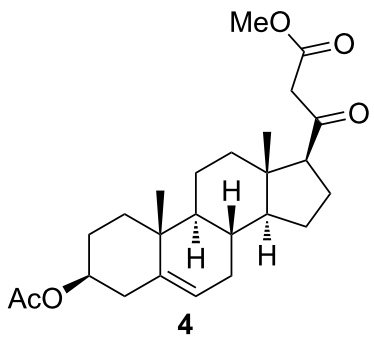

4<smiles>[R]c1ccc(NN)cc1</smiles>

$5 \mathrm{~d}-\mathrm{j}$

$\mathrm{NaOAc}, \mathrm{EtOH}, \mathrm{AcOH}$

$\mathrm{MW}, 120^{\circ} \mathrm{C}$

irradiation time

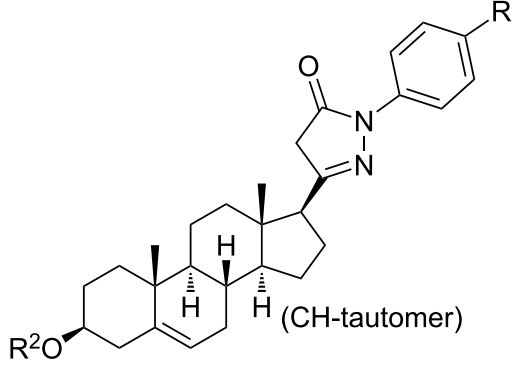

$\begin{aligned} \mathrm{KOH} / \mathrm{MeOH} \longrightarrow 6 \mathrm{~d}-\mathrm{j} & \mathrm{R}^{2}=\mathrm{Ac} \\ \longrightarrow 7 \mathrm{~d}-\mathrm{j} & \mathrm{R}^{2}=\mathrm{H}\end{aligned}$

\begin{tabular}{cccccc}
\hline entry & arylhydrazine hydrochloride & $\mathrm{R}$ & pyrazol-5-one & irradiation time (min) & yield $^{\mathrm{b}}(\%)$ \\
\hline 1 & $\mathbf{5 d}$ & $\mathrm{Me}$ & $\mathbf{6 d}$ & 10 & 86 \\
2 & $\mathbf{5 e}$ & $\mathrm{iPr}$ & $\mathbf{6 e}$ & 10 & 90 \\
3 & $\mathbf{5 f}$ & $t-\mathrm{Bu}$ & $\mathbf{6 f}$ & 10 & 87 \\
4 & $\mathbf{5 g}$ & $\mathrm{OMe}$ & $\mathbf{6 g}$ & 5 & 92 \\
5 & $\mathbf{5 h}$ & $\mathrm{F}$ & $\mathbf{6 h}$ & 30 & 85 \\
6 & $\mathbf{5 i}$ & $\mathrm{Cl}$ & $\mathbf{6 i}$ & 30 & 83 \\
7 & $\mathbf{5 j}$ & $\mathrm{Br}$ & $\mathbf{6 j}$ & 30 & 85 \\
\hline
\end{tabular}

${ }^{a}$ Reagents and conditions: arylhydrazine hydrochloride $\mathbf{5 d}-\mathbf{j} \cdot \mathrm{HCl}$ (1.2 equiv), $\mathrm{NaOAc}$ (1.2 equiv), EtOH $(10 \mathrm{~mL}), 40{ }^{\circ} \mathrm{C}, 10 \mathrm{~min}$, then compound 4 $(1.0 \mathrm{mmol})$ in $\mathrm{AcOH}(20 \mathrm{~mL}), \mathrm{MW}, 120^{\circ} \mathrm{C}, 5-30 \mathrm{~min}$. ${ }^{\mathrm{b}}$ After purification by column chromatography.

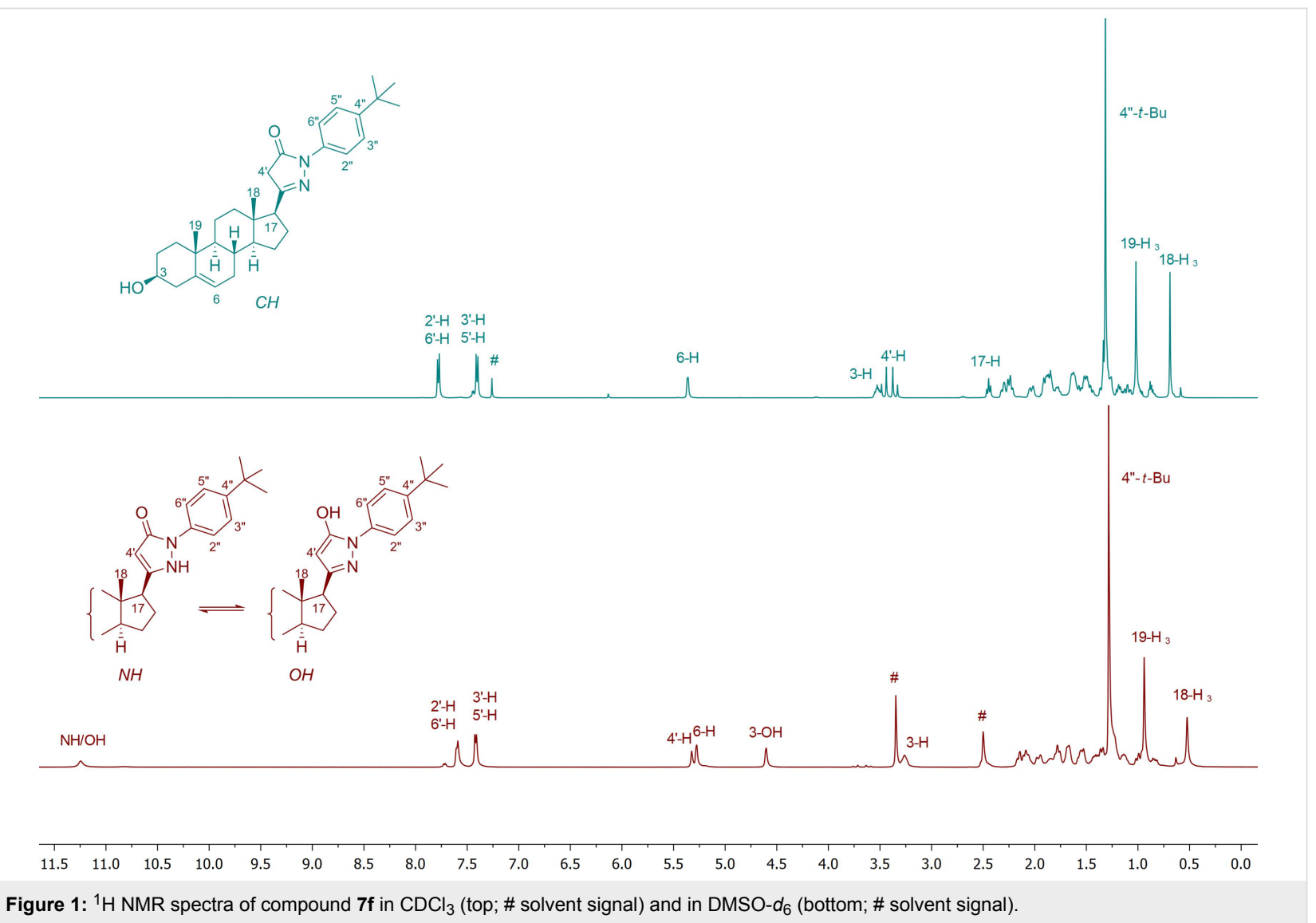

Figure 1: ${ }^{1} \mathrm{H}$ NMR spectra of compound $7 \mathrm{f}$ in $\mathrm{CDCl}_{3}$ (top; \# solvent signal) and in $\mathrm{DMSO}-d_{6}$ (bottom; \# solvent signal). 
liferative effects were determined by means of the MTT assay [20] on a panel of adherent breast cancer cell lines (MCF7, T47D and MDA-MB-231) after treatment for $72 \mathrm{~h}$ (Table 2). All compounds were initially screened at 10 and $30 \mu \mathrm{M}$ concentrations and for those compounds that elicited growth inhibition of at least $50 \%$ at $10 \mu \mathrm{M}$ and around $90 \%$ at $30 \mu \mathrm{M}, \mathrm{IC}_{50}$ values were calculated by using a set of dilutions (Figure S1 in Supporting Information File 1). The viability assays were repeated with the most potent agents $6 \mathbf{h}, \mathbf{7 f}, \mathbf{7 i}$ and $\mathbf{7 j}$ against NIH-3T3 mouse fibroblasts to generate preliminary data concerning the cancer selectivity. Since the molecular site of action of the tested compounds is not known, cisplatin (a clinically used

Table 2: Antiproliferative effects of the synthesized compounds on gynecological cell lines and NIH-3T3 fibroblasts. ${ }^{a}$

compound conc. $(\mu \mathrm{M})$

inhibition of cell proliferation (\%) \pm SEM

[calculated $\mathrm{IC}_{50}(\mu \mathrm{M})$ ]

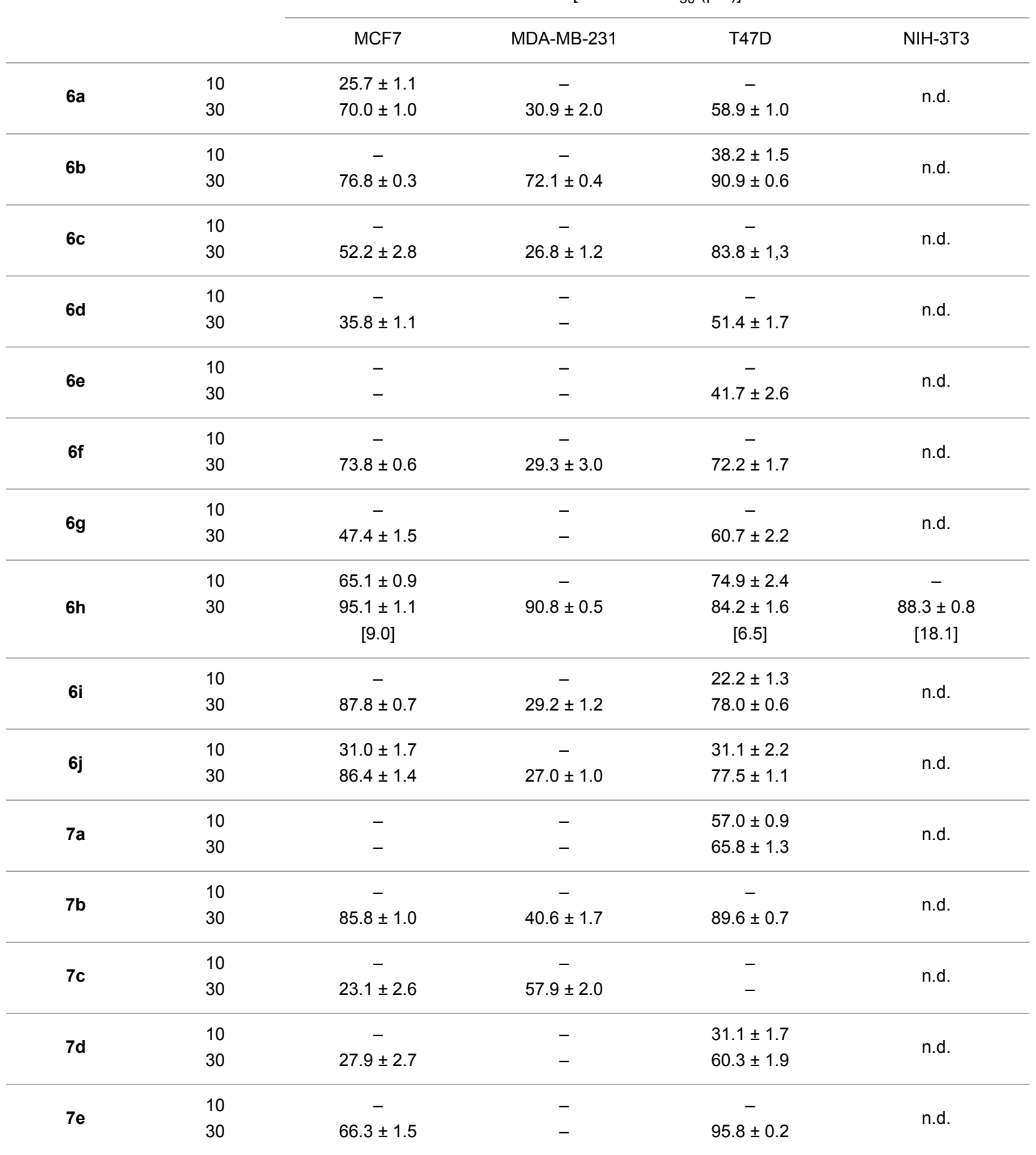


Table 2: Antiproliferative effects of the synthesized compounds on gynecological cell lines and NIH-3T3 fibroblasts. ${ }^{\text {a }}$ (continued)

\begin{tabular}{|c|c|c|c|c|c|}
\hline \multirow{3}{*}{$7 f$} & 10 & $21.1 \pm 2.8$ & $31.3 \pm 1.3$ & $83.1 \pm 1.3$ & - \\
\hline & 30 & $95.8 \pm 0.3$ & $89.6 \pm 0.8$ & $87.5 \pm 0.5$ & $84.6 \pm 1.3$ \\
\hline & & & & [4.3] & [18.2] \\
\hline \multirow{2}{*}{$7 g$} & 10 & - & - & $22.3 \pm 1.3$ & \multirow{2}{*}{ n.d. } \\
\hline & 30 & $40.9 \pm 1.6$ & $39.6 \pm 1.7$ & $55.7 \pm 2.2$ & \\
\hline \multirow{2}{*}{$7 \mathrm{~h}$} & 10 & - & - & - & \multirow{2}{*}{ n.d. } \\
\hline & 30 & $91.3 \pm 0.8$ & $96.8 \pm 0.2$ & $85.2 \pm 1.1$ & \\
\hline \multirow{3}{*}{$7 i$} & 10 & $66.8 \pm 1.7$ & $31.3 \pm 1.5$ & $32.8 \pm 1.3$ & - \\
\hline & 30 & $96.3 \pm 0.2$ & $96.8 \pm 0.2$ & $87.8 \pm 0.5$ & $94.0 \pm 0.5$ \\
\hline & & [6.9] & & & [15.3] \\
\hline \multirow{3}{*}{$7 j$} & 10 & $58.6 \pm 1.2$ & $42.0 \pm 0.8$ & $48.3 \pm 1.9$ & - \\
\hline & 30 & $89.5 \pm 1.1$ & $96.1 \pm 0.2$ & $85.5 \pm 1.2$ & $91.1 \pm 1.0$ \\
\hline & & [8.1] & & & [17.3] \\
\hline \multirow{3}{*}{ cisplatin } & 10 & $66.9 \pm 1.8$ & - & $51.0 \pm 2.0$ & $94.2 \pm 0.4$ \\
\hline & 30 & $96.8 \pm 0.4$ & $71.5 \pm 1.2$ & $55.0 \pm 1.5$ & $96.4 \pm 0.2$ \\
\hline & & {$[5.8]$} & [19.1] & {$[9.8]$} & [3.2] \\
\hline
\end{tabular}

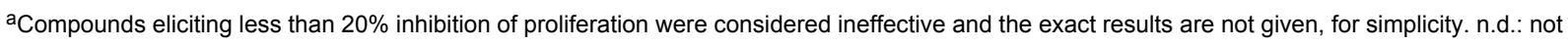
determined.

DNA-binding anticancer agent) was applied as the reference. The results indicated that the $3 \beta$-acetates $\mathbf{6} \mathbf{a}-\mathbf{j}$ exhibited weak or only modest antiproliferative activities, typically eliciting $20-30 \%$ growth inhibition at $10 \mu \mathrm{M}$. However, the $p$-fluoro derivative $\mathbf{6 h}$, proved to be more effective on MCF7 and T47D cells. The deacetylated analogs $\mathbf{7 a}-\mathbf{j}$ generally inhibited cancer cell growth more efficiently. The character of the substituent on the aromatic ring was crucial for the antiproliferative actions on the different cell lines. A tert-butyl group at the para position (7f) appeared favorable against T47D cells resulting in an $\mathrm{IC}_{50}$ value lower than that of the reference cisplatin. While the chloro and bromo-substituted derivatives exerted more pronounced effects on MCF7 cells in their 3-OH form (7i and 7j), the fluoro compound $\mathbf{7 h}$ proved to be less active than its ester 6h. Although the performed viability assay on animal fibroblasts cannot be considered as an appropriate toxicological evaluation, the obtained results are promising and point to a less growth inhibiting action of the compounds on fibroblasts than on cancer cells. All of them displayed less than $20 \%$ growth inhibition at $10 \mu \mathrm{M}$ and their calculated $\mathrm{IC}_{50}$ values proved to be higher than those obtained on the malignant cell lines.

\section{Conclusion}

In summary, a microwave-assisted one-pot method for the facile and efficient synthesis of novel steroidal 17-exo-pyrazol5 '-ones from a $\beta$-ketoester precursor with arylhydrazine hydrochlorides has been developed. An acid-catalyzed thermal decarboxylation of the starting material as an unwanted side reaction could be avoided by applying a one-pot two-step protocol involving the in situ liberation of the reagent from its salt in $\mathrm{EtOH}$ followed by the heterocyclization reaction through the addition of $\mathrm{AcOH}$. Some of the presented compounds $\mathbf{6 h}$, 7f, $7 \mathbf{i}$ and $7 \mathbf{j}$ exerted considerable antiproliferative activity with promising cancer selectivity on a panel of human breast cancer cell lines. This indicates that the pyrazolone heterocyclic ring at the $17 \beta$ position is a promising scaffold for the design of anticancer agents of the $\Delta^{5}$ androstene series.

\section{Supporting Information}

Experimental procedures for compounds $\mathbf{6 a}-\mathbf{j}, \mathbf{7 a}-\mathbf{j}$ and $\mathbf{8}$, their ${ }^{1} \mathrm{H},{ }^{13} \mathrm{C}$ NMR, MS, IR, elemental analysis data and the copies of their NMR spectra.

\section{Supporting Information File 1}

Experimental part.

[https://www.beilstein-journals.org/bjoc/content/ supplementary/1860-5397-14-236-S1.pdf]

\section{Acknowledgements}

Financial support by National Research, Development and Innovation Office - NKFIH through projects GINOP-2.3.2-152016-00038 and OTKA-109107 is gratefully acknowledged. 


\section{ORCID ${ }^{\circledR}$ iDs}

Gergő Mótyán - https://orcid.org/0000-0002-0741-106X Márton Attila Kiss - https://orcid.org/0000-0003-3844-3758 Éva Frank - https://orcid.org/0000-0002-1332-0551

\section{References}

1. Salvador, J. A. R.; Pinto, R. M. A.; Silvestre, S. M. J. Steroid Biochem. Mol. Biol. 2013, 137, 199-222. doi:10.1016/j.jsbmb.2013.04.006

2. DeVore, N. M.; Scott, E. E. Nature 2012, 482, 116-119. doi:10.1038/nature10743

3. Njar, V. C. O.; Brodie, A. M. H. J. Med. Chem. 2015, 58, 2077-2087. doi:10.1021/jm501239f

4. Frank, É.; Schneider, G. J. Steroid Biochem. Mol. Biol. 2013, 137, 301-315. doi:10.1016/j.jsbmb.2013.02.018

5. Kovács, D.; Mótyán, G.; Wölfling, J.; Kovács, I.; Zupkó, I.; Frank, É. Bioorg. Med. Chem. Lett. 2014, 24, 1265-1268. doi:10.1016/j.bmcl.2014.01.069

6. Iványi, Z.; Wölfling, J.; Görbe, T.; Szécsi, M.; Wittmann, T.; Schneider, G. Steroids 2010, 75, 450-456. doi:10.1016/j.steroids.2010.02.013

7. Ling, Y.-z.; Li, J.-s.; Liu, Y.; Kato, K.; Klus, G. T.; Brodie, A J. Med. Chem. 1997, 40, 3297-3304. doi:10.1021/jm970337k

8. Kovács, D.; Wölfling, J.; Szabó, N.; Szécsi, M.; Schelz, Z.; Zupkó, I.; Frank, É. Eur. J. Med. Chem. 2016, 120, 284-295. doi:10.1016/j.ejmech.2016.05.006

9. Li, J.; Zhao, X.; Li, L.; Yuan, Z.; Tan, F.; Shi, B.; Zhang, J. Steroids 2016, 107, 45-54. doi:10.1016/j.steroids.2015.12.018

10. Shamsuzzaman; Mashrai, A.; Ahmad, A.; Dar, A. M.; Khanam, H.; Danishuddin, M.; Khan, A. U. Med. Chem. Res. 2014, 23, 348-362. doi:10.1007/s00044-013-0636-y

11. Prajuli, R.; Banerjee, J.; Khana, H. Orient. J. Chem. 2015, 31 , 2099-2106. doi:10.13005/ojc/310430

12. Ma, R.; Zhu, J.; Liu, J.; Chen, L.; Shen, X.; Jiang, H.; Li, J. Molecules 2010, 15, 3593-3601. doi:10.3390/molecules15053593

13. Ekekwe, N. D.; Arinze, A. J.; Nnanna, L. A.; Ukpabi, C. F.; Agwu, A.; Ogwuegbu, M. O. C. Am. J. Chem. 2012, 2, 52-56. doi:10.5923/j.chemistry.20120202.10

14. Tarabová, D.; Soralová, S.; Breza, M.; Fronc, M.; Holzer, W.; Milata, V. Beilstein J. Org. Chem. 2014, 10, 752-760. doi:10.3762/bjoc.10.70

15. Pal, S.; Mareddy, J.; Devi, N. S. J. Braz. Chem. Soc. 2008, 19, 1207-1214. doi:10.1590/S0103-50532008000600023

16. Bagley, M. C.; Baashen, M.; Paddock, V. L.; Kipling, D.; Davis, T. Tetrahedron 2013, 69, 8429-8438. doi:10.1016/j.tet.2013.07.055

17. Vaddula, B. R.; Varma, R. S.; Leazer, J. Tetrahedron Lett. 2013, 54, 1538-1541. doi:10.1016/j.tetlet.2013.01.029

18. Holzer, W.; Kautsch, C.; Laggner, C.; Claramunt, R. M.; Pérez-Torralba, M.; Alkorta, I.; Elguero, J. Tetrahedron 2004, 60, 6791-6805. doi:10.1016/j.tet.2004.06.039

19. Claramunt, R. M.; López, C.; Santa María, M. D.; Sanz, D.; Elguero, J. Prog. Nucl. Magn. Reson. Spectrosc. 2006, 49, 169-206. doi:10.1016/j.pnmrs.2006.07.001

20. Mosmann, T. J. Immunol. Methods 1983, 65, 55-63. doi:10.1016/0022-1759(83)90303-4

21. Zhu, N.; Ling, Y.; Lei, X.; Handratta, V.; Brodie, A. M. H. Steroids 2003, 68, 603-611. doi:10.1016/S0039-128X(03)00082-5

22. Kovács, D.; Wölfling, J.; Szabó, N.; Szécsi, M.; Kovács, I.; Zupkó, I.; Frank, É. Eur. J. Med. Chem. 2013, 70, 649-660. doi:10.1016/j.ejmech.2013.10.038
23. Kovács, D.; Wölfling, J.; Szabó, N.; Szécsi, M.; Minorics, R.; Zupkó, I.; Frank, É. Eur. J. Med. Chem. 2015, 98, 13-29. doi:10.1016/j.ejmech.2015.05.010

24. Magano, J.; Nanninga, T. N.; Winkle, D. D. Tetrahedron Lett. 2008, 49, 2956-2959. doi:10.1016/j.tetlet.2008.03.004

25. Allan, K. M.; Hong, B. D.; Stoltz, B. M. Org. Biomol. Chem. 2009, 7, 4960-4964. doi:10.1039/B913336D

26. Lu, Y.; Chen, J.; Janjetovic, Z.; Michaels, P.; Tang, E. K. Y.; Wang, J.; Tuckey, R. C.; Slominski, A. T.; Li, W.; Miller, D. D. J. Med. Chem. 2012, 55, 3573-3577. doi:10.1021/jm201478e

27. Mótyán, G.; Kovács, F.; Wölfling, J.; Gyovai, A.; Zupkó, I.; Frank, É. Steroids 2016, 112, 36-46. doi:10.1016/j.steroids.2016.04.014

28. Enchev, V.; Neykov, G. D. J. Mol. Struct.: THEOCHEM 1992, 258, 217-234. doi:10.1016/0166-1280(92)85065-S

29. Gupta, P.; Gupta, J. K.; Halve, A. K. Int. J. Pharm. Sci. Res. 2015, 6, 2291-2310. doi:10.13040/IJPSR.0975-8232.6(6).2291-10

30. Sheng, X.; Hua, K.; Yang, C.; Wang, X.; Ji, H.; Xu, J.; Huang, Z.; Zhang, Y. Bioorg. Med. Chem. Lett. 2015, 25, 3535-3540. doi:10.1016/j.bmcl.2015.06.090

31. Alkorta, I.; Goya, P.; Elguero, J.; Singh, S. P. Natl. Acad. Sci. Lett. (India) 2007, 30, 139-159.

\section{License and Terms}

This is an Open Access article under the terms of the Creative Commons Attribution License (http://creativecommons.org/licenses/by/4.0). Please note that the reuse, redistribution and reproduction in particular requires that the authors and source are credited.

The license is subject to the Beilstein Journal of Organic Chemistry terms and conditions: (https://www.beilstein-journals.org/bjoc)

The definitive version of this article is the electronic one which can be found at: doi:10.3762/bjoc. 14.236 